afforded by the published data. In fact, the report generally bears evidence of having been drawn up on the supposition that the data are practically complete, whereas such perfection, or anything like it, is an absolute impossibility. The committee, and others interested in bird migration, would do well to remember that not one bird in a thousand that arrives on our shores, or which proceeds inland or coastwise, comes under the notice of competent observers, numerous though they be. This important consideration makes it imperative that some years must be devoted to the amassing and testing of materials ere the foundations of a trustworthy report can be laid.

The records collected by the committee are numerous, and, as interim reports seem to be desired, may be considered of sufficient interest and value to render them worthy of publication. There are a number of unfortunate slips in the report, some of which are so palpable that it seems strange that $\mathrm{Mr}$. Bonhote's-the preparer's-colleagues on the committee did not detect them.

W. E. C.

\section{PRESERVATION OF MEMORIALS IN} AMERICA.

$\mathrm{A}^{\mathrm{S}}$ an outcome of

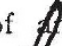

artifle which appeared in "Landscape Protectio in Germany," the American Scenic and Histgric 1 re rvation Society has sent us some of its liteptur This society was incorporated in 1895 a $8 \mathrm{cial}$ act of the Legislature of the State of fork, and holds, therefore, a semiofficial position in that State. It has to report annually to the Legislature, and has a right to make recommendations regarding improvements to any of the municipalities.

The society's aims are summed up to a large extent in its name. It endeavours " to protect beautiful features of the natural landscape from disfigurement, either by physical alterations or by the erection of unsightly. signs and structures, and to preserve from destruction remarkable geological formations or organic growths possessing an artistic or scientific value"; and it also endeavours "to save from obliteration names, places, and objects identified with local, State and national history; to erect suitable historical memorials where none exist."

In towns and villages it aims at procuring parks and open spaces, where necessary for the health and comfort of the inhabitants; it makes every effort to prevent the destruction of trees, and stimulates as much as possible a desire for local beautification in the minds of the public.

The funds depend on the members' subscriptions and voluntary contributions. The Government gives no financial support, but public money is occasionally placed at its disposal for acquiring or keeping in order properties for the public benefit. It is also empowered, according to its charter, "to receive real or personal property, in fee, or trust ... and to ad. minister it as a public trustee."

By means of meetings, free lectures, circulating historical pamphlets, and various educational means, the society endeavours to engrain in the people an appreciation of the beauties of nature, and also a patriotic interest in historical localities. Its efforts are becoming fully appreciated all over America, for its services are requisitioned in many different parts and in many different ways, the verifying of historical sites and putting up of tabiets to commemorate noteworthy events being the most usual. America is much to be congratulated on having such a society, and especially one that is so active.

\section{NOTES}

Prof. J. B. ARMer, F.R.S., has accepted the editorship of the Ganers' Chronicle in succession to the late Dr. M. T. Mastefs, F.R.S.

THE inaugural address of the coming session of the Royal Scottish Gfographical Society will be delivered by Lord Milner it ling Synod Hall, Edinburgh, on Wednesday, November 13

WE regret to see the announcement that Prof. L. F. Vernon Harcoury emeritus professor of civil engineering at University follege, London, died on Saturday, September 14, at sixty-eight years of age.

THE managers of the Metropolitan Asylums Board have approved of the gection at Belmont, Surrey, of new laboratories for the preparation of diphtheria anti-toxin and for bacterieroy al work. The total expenditure on the laboratories is not to exceed $6500 l$.

Symons's Monthly Magazine, the present issue of which is the five hundredth number of that interesting organ of meteorological opfion, annoutrces that Dr. Gr. Hellmann has been appoifed professor of metkorology in the University of Bermf and director of the Prussian Meteorological Service, lin succession to the late Prof. von Bezold.

A telegram from Seattle states that a volcano in the Aleutian Islands byme active on September $\mathbf{I}$ and 2, and that ash ejcfed from it fell upon twenty villages. A disturbance reard by a seismograph at Washington on September 2 appegrs to have been due to this eruption.

THE Royal Geographical Society has received the following telegram referring to the Anglo-American Polar Expedition, signed by Captain Mikkelsen and Mr. Leffingwell :- "Sledge ty covering 500 miles . crossed edge continental shelf wice soundings 5o miles off coast and beyond 630 metloy no bottom ship lost next year continuation geology thnography surveying and exploration Beaufort Sea."

The Royal Commission on Mines has appointed Dr. A. E. Boycott to make an investigation with a view to determine whether there are any indications of the disease known as ankylofomiasis (miner's worm) in coal mines in Great Britho. Mr. John Cadman has also been appointed to mak a series of observations and tests of mine air in connection with the question referred to the commission whether any steps should be taken to lay down a standard of ventilation in mines.

Prof. E. Heckel, director of the Colonial Institute at Marseilles, has been awarded the gold medal founded by Dr. F. A. Flückiger, of Strassburg, in 1893 , and awarded every five years, 12 recognition of steps taken to promote the advancemenf of scientific pharmacy, irrespective of nationality. $\mathrm{E}$. $M$. Holmes, the curator of the museums of the pharmaceutical Society of Great Britain, received the first ${ }_{\text {medal, }}$ and the second was presented to Dr. C. Schmidt, of Marburg.

The discovery of an interesting dene-hole on the south side of Windmill Hill, Gravesend, was described in the Times of Septempor 14. in pears that a workman engaged in makjog excay tions for building purposes discovered a shaff, raty less than 3 feet wide, which descended vertidaly to a depth of 55 feet from the surface, when it entered the chalk, and after piercing 3 feet of this rock opened out into a large artificial cavern. This cave was divided into two chambers by a roughly hewn 